\title{
Teucrium thieleanum (Labiatae), a new species from Victoria, Australia
}

\author{
Barry J. Conn \\ National Herbarium of New South Wales, Mrs Macquaries Road, Sydney NSW 2000 Australia
}

\begin{abstract}
Teucrium thieleanum is an erect subshrub that is moderately to densely glandular hairy, with simple, multicellular podiate glands, subsessile hemispherical glands, as well as long and short eglandular hairs, ovate to broadly ovate leaves with crenate to lacerated margin. This paper provides a full description of Teucrium thieleanum, habitat notes, botanical illustration, and a key to distinguish this species from other named Teucrium species in Victoria.
\end{abstract}

\section{Introduction}

This species is only known from two localities in East Gippsland, Victoria (Australia). The earliest collection being by Neville Walsh and David Albrecht, gathered in 1988 from the Marble Gully area, with later collections by Kevin Thiele, gathered in November 2004 and January 2005, both from Little River Gorge. With the description of this new species, in this paper, there are now five known species of Teucrium occurring in Victoria.

Terminology follows Conn (1984). Inflorescence terminology follows Briggs and Johnson (1979), except for modifications by Conn (1995).

Teucrium thieleanum B.J.Conn, sp. nov.

T. corymboso foliis latioribus $(24-45 \mathrm{~mm})$, margine crenato vel lacerato, prophyllis latioribus $(0.6-0.8 \mathrm{~mm})$, indumento glandifero longo subsessilique (vice subsessili modo) differt.

Type: Victoria: East Gippsland: Little River Gorge above 'BBC Camp', K.R. Thiele 2992, 24 Nov. 2004 (holo NSW 677435; iso MEL 2264890).

Erect subshrub 1-1.5 $\mathrm{m}$ high, branches above the base (Thiele 2992). Branches \pm quadrangular, slightly ridged on angles, densely hairy; hairs simple, straight to slightly curved, multicellular, glandular, \pm spreading (patent to slightly antrorse or retrorse); internodes with short and long hairs, short hairs $0.1-0.2 \mathrm{~mm}$ long, translucent throughout or with gland white to pale golden-coloured, long hairs $0.5-0.9 \mathrm{~mm}$ long; nodes with longer spreading hairs 1-1.5 mm long, moderately glandular with hemispherical, subsessile glands. Leaves aromatic, with petiole $7-8 \mathrm{~mm}$ long; lamina ovate to broadly ovate, less frequently elliptic, greyish green, 40-50 mm long, 24-45 mm wide, with length 1-1.7 times width, distance from base of maximum width $0.3-0.5$ times total lamina length; 
abaxial surface sparsely glandular hairy (average density $8-10$ hairs per $\mathrm{mm}^{2}$ ), hairs \pm patent, c. $0.1 \mathrm{~mm}$ long, with longer hairs on veins and margin (hairs $0.2-0.4 \mathrm{~mm}$ long), very densely covered with subsessile glands (as per branches); adaxial surface moderately glandular hairy (average density c. 12 hairs per $\mathrm{mm}^{2}$ ), hairs \pm patent, $0.8-1.3 \mathrm{~mm}$ long, densely covered with subsessile glands (as for branches); base decurrent; margin crenate to lacerate, slightly recurved, with apex of teeth rounded to subacute (when lacerate); apex subacute; venation distinct, midvein and secondary veins slightly raised on abaxial surface. Inflorescence frondose-bracteose, many-flowered; uniflorescence dichasial, (5-)7-15-flowered (7-flowered distally). Podium 2-5.5(-7) mm long, densely hairy (as for branches), hairs $0.1-0.3 \mathrm{~mm}$ long. Prophylls \pm persistent, inserted near middle of podium (propodium 2-3 $\mathrm{mm}$ long; anthopodium 1.8-2 $\mathrm{mm}$ long, with propodium 1-1.5 times length of anthopodium), opposite to subopposite; lamina narrowly triangular, $1-1.5 \mathrm{~mm}$ long, $0.6-0.8 \mathrm{~mm}$ wide, slightly concave lengthwise to almost flat, densely hairy with short hairs (as for branches). Calyx dull green, campanulate; outer surface densely hairy with short hairs (as for branches), midveins prominent, ridged, with slightly longer glandular hairs; tube 1-1.5 mm long, inner surface glabrous; lobes equal, narrowly triangular, c. $2 \mathrm{~mm}$ long, $0.8-1 \mathrm{~mm}$ wide at base, with length 2-2.5 times width, inner surface sparsely hairy (hairs as for branches), apex subacute. Corolla 6-7.5 mm long, white; outer surface of lobes moderately hairy, eglandular hairs $0.1-0.2$ $\mathrm{mm}$ long, translucent to white, simple, multicellular, spreading to antrorse, sparsely to moderately glandular with subsessile hemispherical glands; inner surface sparsely hairy in tube, with hairs simple, spreading, c. $0.1 \mathrm{~mm}$ long; tube 1.5-2 mm long; lobes glabrous, or with an occasional eglandular hair, inconspicuously glandular with minute, subsessile hemispherical glands; abaxial median lobe spathulate, slightly involuteconduplicate, 3-3.6 mm long, 2-2.5 mm long, with length c. 1.5 times width, apex rounded; lateral lobes and adaxial median lobe pair slightly elliptic to oblong, 2-3 mm long, each lobe 1-1.3 mm wide, with length 2-2.3 times width, apex obtuse. Stamens inserted $0.5-0.7 \mathrm{~mm}$ above base of corolla; filaments arching towards adaxial inner surface of corolla, 6-8 mm long, sparsely hairy near base (as for inner surface of corolla tube), abaxial filament-pair longer than adaxial filaments; anthers $0.5-0.6 \mathrm{~mm}$ long, c. 0.3 $\mathrm{mm}$ wide, connective with a line of hemispherical, white glands. Pistil 10-11 mm long; ovary cylindrical to slightly obovoid, $0.3-0.5 \mathrm{~mm}$ long, diameter $0.6-0.7 \mathrm{~mm}$, lobes c. 0.1 $\mathrm{mm}$ long, moderately hairy distally, with hairs eglandular, white, \pm curled, moderately glandular (glands subsessile, hemispherical); style c. $9 \mathrm{~mm}$ long, strongly curved (towards adaxial plane); stigma lobes $0.7-1 \mathrm{~mm}$ long, slightly unequal, soon becoming \pm strongly reflexed. Fruiting propodium and anthopodium extended to c. $3 \mathrm{~mm}$ long. Fruiting calyx enlarged, 3-4 mm long, mouth 2-2.5 mm diameter (compared to c. $1 \mathrm{~mm}$ diameter in flower), becoming pale brown, densely glandular. Mature mericarps $1.5-2 \mathrm{~mm}$ long, surface light to dark brown, with irregular longitudinal ridges (corrugated), moderately hairy and glandular (as for ovary). Figure 1.

Other specimens examined: Victoria: East Gippsland: Little River Gorge below 'Farm Creek', K.R. Thiele 2994, 5 Jan 2005 (MEL n.v., NSW); Marble Gully area, 200 m S of Old Hut Creek, N.G. Walsh 2089 \& D.E. Albrecht, 30 Jun 1988 (AD, MEL, NSW)

Distribution: this species is only known from East Gippsland region of Victoria.

Habitat: this species is recorded as growing in Eucalyptus albens grassy woodland on loamy soils derived from Snowy River volcanics (Thiele $2992 \& 2994$ ) and from the margin of dense Pomaderris sp. aff. oraria - Helichrysum adnatum shrubland on marble substrate (Walsh 2089). 


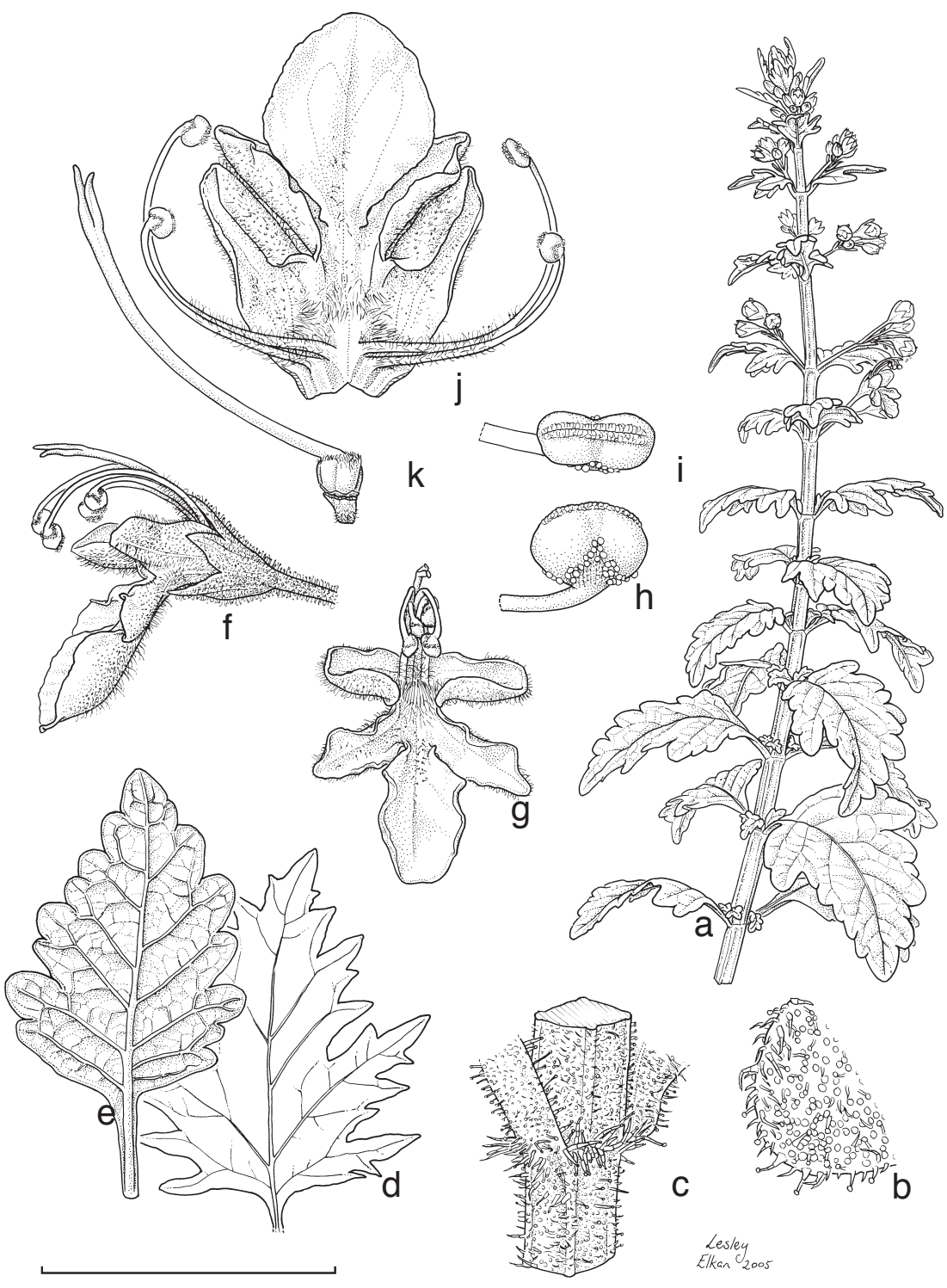

Fig. 1. Teucrium thieleanum B.J.Conn a, branchlet, showing flowers and flower buds; b, detail of adaxial leaf surface showing eglandular hairs, plus podiate and hemispherical glands; c, detail of branchlet showing indumentum with long multicellular podiate glands at node between leaf bases; $\mathbf{d}$, leaf with margin lacerate; $\mathbf{e}$, leaf, showing prominent venation of abaxial surface and margin crenate; f, flowers, lateral view, showing calyx, corolla, exserted style, stigma and stamens; $\mathbf{g}$, corolla, ventral view, showing position of stamens and stigma; $\mathbf{h}$, anther, dorsal view, showing line of hemispherical glands on connective; $\mathbf{i}$, anther, ventral view; $\mathbf{j}$, open corolla, showing hairy inner surface of tube and androecium, and comparative lengths of stamens; $\mathbf{k}$, gynoecium, showing indumentum on distal surface of ovary, displaced alignment of style (towards adaxial inner surface of corolla), and slightly unequal stigma lobes. (a, b, e-k from living material of Thiele 2994; c from herbarium material of Thiele 2994, d from Thiele 2992). Scale bar: $\mathrm{a}=50$ $\mathrm{mm} ; \mathrm{b}=2 \mathrm{~mm} ; \mathrm{c}=4 \mathrm{~mm} ; \mathrm{d} \& \mathrm{e}=40 \mathrm{~mm} ; \mathrm{f} \& \mathrm{~g}=10 \mathrm{~mm} ; \mathrm{h} \& \mathrm{i}=2.5 \mathrm{~mm} ; \mathrm{j} \& \mathrm{k}=7.5 \mathrm{~mm}$. 
Etymology: the specific epithet thieleanum recognises the significant contribution that Kevin Thiele has made to systematic botany. He is also the collector of the type material.

Notes: this species has multi-branched botryoidal superconflorescences, with all axes anthotelic, consisting of thyrsoid conflorescences. Each conflorescence usually consists of 7-flowered simple dichasia throughout much of its length, whereas 15-flowered dichasia are present towards the base. However, fewer-flowered dichasia are occasionally present, especially when the plant is beginning to flower. The inflorescence is leafy throughout much of its length, with a gradual reduction in leaf size from base to apex. However, the bracts at the distal end of the $\mathrm{a}_{1}$ internode of the uniflorescence are slightly lacerated, like normal leaves. Ultimately, the leaves are reduced such that they are prophyll-like distally. Teucrium thieleanum is morphologically very similar to T. corymbosa. The characters that distinguish these two species are summarised in the identification key (see below).

Conservation status: although the conservation status of this species is unknown, it has been recorded as locally 'uncommon' (Walsh 2089) and 'infrequent' (Thiele 2992 and 2994).

\section{Identification of Teucrium thieleanum from other Victorian species}

The identification key provided by Conn (1999, p. 457) to the species of Teucrium occurring in Victoria is here modified to distinguish this new species from the other species.

1. Leaves entire, or trifoliate with linear entire leaflets; plants greyish from a very dense, short indumentum

1. Leaves toothed or deeply lobed almost to midrib; plants green

2. Leaves trifoliate (or sometimes the lowermost entire)

T. albicaule

2. Leaves simple throughout

T. racemosum

3. Leaves entire, deeply lobed; hairs mostly branched

T. sessiliflorum

3. Leaves toothed, not deeply lobed; hairs simple, never branched 4

4. Leaves with margin serrate, lamina 6-20 mm wide; corolla with abaxial median lobe (lip) 6-9 mm long; prophylls narrow (1-1.3 mm long, c. $0.2 \mathrm{~mm}$ wide); branches with simple, short, antrorse eglandular hairs and subsessile hemispherical glands

T. corymbosum

4. Leaves with margin crenate to slightly lacerate, lamina $24-45 \mathrm{~mm}$ wide; corolla with abaxial median lobe (lip) 3-3.6 mm long; prophylls broad (1-1.5 mm long, 0.6-0.8 mm wide); branches with simple, short and long eglandular hairs, straight to slightly curved, and multicelled, podiate glands and subsessile hemispherical glands

T. thieleanum

\section{Acknowledgments}

The botanical illustration of Teucrium thieleanum was skillfully drawn by Lesley Elkan (NSW). Kevin Thiele (CANB) brought this taxon to my attention. Peter Wilson (NSW) kindly corrected the Latin diagnosis. 


\section{References}

Briggs BG \& Johnson LAS (1979) Evolution in the Myrtaceae - Evidence from infloresence structure. Proceedings of the Linnean Society of New South Wales 102: 157-256.

Conn BJ (1984) A taxonomic revision of Prostanthera Labill. Section Klanderia (F.v.Muell.) Benth. (Labiatae). Journal of the Adelaide Botanic Gardens 6: 207-348.

Conn BJ (1995) Description of inflorescence axes in the genus Logania R.Br. (Loganiaceae). Kew Bulletin 50: 777-783.

Conn BJ (1999) Teucrium. Pp. 456-459 in Walsh NG \& Entwisle TJ (eds) Flora of Victoria, vol. 4. (Inkata Press: Melbourne)

Manuscript received 28 October 2005, accepted 9 December 2005 